medRxiv preprint doi: https://doi.org/10.1101/2021.01.19.21250059; this version posted January 20, 2021. The copyright holder for this preprint (which was not certified by peer review) is the author/funder, who has granted medRxiv a license to display the preprint in

All rights reserved. No reuse allowed without permission.

\title{
Systematic Review and Meta-analysis of Immunomodulator and Biologic Therapies for Treatment of Chronic Pouchitis
}

\author{
Emi Khoo ${ }^{1,2}$, Andrew Lee ${ }^{1,2}$, Teresa Neeman ${ }^{3}$, Yoon-Kyo An ${ }^{2,4}$, Jakob Begun ${ }^{2,4}$ \\ ${ }^{1}$ Mater Hospital Brisbane, Brisbane, QLD \\ ${ }^{2}$ School of Medicine, University of Queensland, Brisbane, QLD \\ ${ }^{3}$ Biology Data Science Institute, Australian National University, Canberra, ACT \\ ${ }^{4}$ Mater Research, Brisbane, QLD
}

\section{Authorship statement}

Guarantor of article: Emi Khoo

Specific author contribution:

Emi Khoo performed study selection, data extraction, grading of bias and wrote the paper

Andrew Lee executed the online database search, performed study selection, grading of bias and edited the manuscript

Teresa Neeman performed the statistical analysis, and edited the manuscript

Yoon-Kyo An and Jakob Begun designed the study, reviewed included studies, supervised data analysis and interpretation, and edited the manuscript

All authors have approved the final version of the article.

\section{Conflict of interest}

EK, AL and TN have no conflict of interest

$Y A$ has received speaking and consulting fees from Janssen, Takeda, Pfizer, Abbvie

JB has received consulting and speaking fees from Janssen, Takeda, Pfizer, Abbvie, Celltrion, Sandoz

\section{Summary}

Background Pouchitis is a common complication after restorative proctocolectomy with ileal pouch-anal anastomosis (IPAA). Although antibiotics are the primary therapy for acute pouchitis, a proportion of patients developed chronic antibiotic-dependent pouchitis (CADP) or antibiotic-refractory pouchitis (CARP). The efficacy of second line immunomodulator and biologic therapies for chronic pouchitis remain undefined. We performed a systematic review and metanalysis of published studies to assess their efficacy.

Method The online EMBASE database was searched for full-text articles describing the treatment of chronic pouchitis meeting our criteria. Post-induction clinical and endoscopic response and remission rates were extracted and combined for meta-analyses. The rate of treatment discontinuation and safety profiles were also assessed.

Results A total of 21 full-text articles were included in this meta-analysis representing 491 patients. The overall clinical response rate was $49 \%$ with clinical remission rate of $34 \%$. The overall endoscopic response and remission rates were $53 \%$ and $36 \%$ respectively. The safety profile of individual agents was reassuring, but vedolizumab appears to have a more favorable safety profile.

Conclusion This review and meta-analysis identified the effectiveness of vedolizumab and ustekinumab in achieving clinical and endoscopic response in chronic pouchitis, with a reassuring safety profile. There is limited data regarding use of immunomodulators and no conclusion can be drawn. Further studies are required to define the comparative

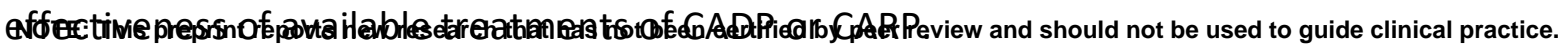


medRxiv preprint doi: https://doi.org/10.1101/2021.01.19.21250059; this version posted January 20, 2021. The copyright holder for this preprint (which was not certified by peer review) is the author/funder, who has granted medRxiv a license to display the preprint in perpetuity.

All rights reserved. No reuse allowed without permission.

\section{Keywords}

Immunomodulator, biologic therapies, chronic pouchitis

\section{Introduction}

lleal pouch-anal anastomosis (IPAA) is a restorative surgical intervention following proctocolectomy for management of severe refractory ulcerative colitis (UC). ${ }^{1}$ An IPAA may also be formed after proctocolectomy for other indications such as familial adenomatous polyposis or colonic high-grade dysplasia secondary to inflammatory bowel disease (IBD). ${ }^{2}$ Pouchitis is a common complication of IPAA and affects up to $20 \%$ of patients within the first year post pouch formation, and up to $40 \%$ at 5 years. ${ }^{3}$ The Crohn's and Colitis Foundation of America Partners cohort reported an overall incidence of pouchitis in up to $79 \%$ of patients after IPAA for UC. ${ }^{4}$ Interestingly pouchitis is more common in patients who had an IPAA performed for UC than for other indications, indicating that a similar pathogenesis may underly the development of pouchitis and UC. Symptoms of pouchitis can be debilitating, including increased stool frequency, rectal bleeding, abdominal cramping, urgency and faecal incontinence. ${ }^{5} \mathrm{~A}$ diagnosis of pouchitis should be confirmed with endoscopy and mucosal biopsy of the pouch, in order to exclude other conditions including cuffitis and functional pouch disorder. ${ }^{6}$ Common findings on endoscopy include edematous mucosa, granularity, friability, loss of vascular pattern, mucous exudates and ulceration of pouch. ${ }^{7}$

The first line therapy for acute pouchitis is antibiotics, most commonly metronidazole and ciprofloxacin, which is highly effective. ${ }^{11}$ Up to $87.5 \%$ of patients treated with antibiotics achieved clinical remission, while $88 \%$ achieved clinical response. ${ }^{1}$ Similarly, significant improvements of median PDAl score have been described with antibiotic therapy, which was strongly correlated with the patients' satisfaction and quality of life. ${ }^{12}$ However, up to $15 \%$ of patients develop chronic antibiotic-dependent pouchitis (CADP) or chronic antibioticresistant pouchitis (CARP). ${ }^{13-14} \mathrm{~A}$ diagnosis of CADP or CARP is established if patients require continuous antibiotic therapy for more than 4 weeks within a 12 month period to relieve symptoms, or fail to achieve an adequate response despite a 4 week course of antibiotic use respectively.

Immunomodulator and biologic therapies are often prescribed for management of chronic pouchitis. These medications target pro-inflammatory pathways that are believed to drive inflammation in chronic pouchitis. Evidence supporting their use is limited to retrospective cohort studies and pilot studies. High level comparative evidence on immunomodulator and biologic therapies for chronic pouchitis is needed to support a treatment algorithm for CARP and CADP. To investigate the available evidence for therapies in chronic pouchitis we performed a systemic review and meta-analysis to determine the efficacy of immunomodulator and biologic therapies for treatment of chronic pouchitis in adult patients who have undergone an IPAA for UC.

\section{Methods}

Our study was conducted in accordance with the Preferred Items for Systematic Reviews and Meta-analysis [PRISMA] guidelines. Our systematic review was registered with the 
medRxiv preprint doi: https://doi.org/10.1101/2021.01.19.21250059; this version posted January 20, 2021. The copyright holder for this preprint (which was not certified by peer review) is the author/funder, who has granted medRxiv a license to display the preprint in

All rights reserved. No reuse allowed without permission.

International prospective register of systematic reviews (PROSPERO) on $7^{\text {th }}$ August 2020 (reference number: CRD42020196627).

\section{Study Selection}

A structured search of the EMBASE database was performed on $1^{\text {st }}$ Dec 2019 , to identify all studies that assessed the efficacy of immunomodulators and/or biologic therapies in chronic pouchitis. The Medical Subject Heading (MeSH) terms used were "pouchitis", "ulcerative colitis", "therapy", "immunomodulating agent", "methotrexate", "azathioprine", "mercaptopurine", "tioguanine", "thioguanine derivatives", "tumor necrosis factor inhibitor", "infliximab", "adalimumab", "golimumab", "vedolizumab" and "ustekinumab".

Articles meeting the search criteria were screened by two authors (EK, $A L$ ). Shortlisted publications were reviewed independently by two authors (YA, JB). Discrepancies at either stage of screening were resolved by discussion. For the purpose of this study, inclusion criteria were: adult patients who have undergone IPAA for indication of UC; articles that were published in complete form in peer-reviewed journals, either prospective or retrospective studies; articles that reported at least 3 patients treated for chronic pouchitis.

Articles were excluded if they were review articles, published in abstract form only, nonEnglish language articles, studies reporting less than three cases of chronic pouchitis and those that reported duplicate results. Those studies which reported outcomes of nonimmunomodulator and non-biologic interventions, were also excluded.

\section{Data Extraction and Outcome Measures}

Baseline characteristics, efficacy and safety were extracted from each eligible study. The primary outcome was the clinical response rate to immunomodulator or biologic therapy. Secondary outcomes included the clinical remission rate, endoscopic response rate, mucosal healing rate, and rate of discontinuation of immunomodulator or biologic therapy when reported. Clinical response and endoscopic response were defined as reduction of clinical and endoscopic sub score of PDAl by two or more, respectively. The definitions of clinical remission and mucosal healing were clinical and endoscopic sub scores of the PDAI of less than three. Reasons for discontinuation were extracted and included serious adverse events, surgical intervention and switch of biologic therapy due to treatment failure. It was anticipated that there would be variability in time points for assessment and follow up duration in each study. This review aimed to assess measured outcomes, at six months (with a four month window) following commencement of intervention. The reasons for discontinuation were reported at the end of follow up period.

\section{Grading of Evidence}

Assessment of quality and risk of bias was completed by two independent authors (EK, $A L$ ), based on the Oxford Centre for Evidence-Based Medicine 2011 Levels of Evidence. ${ }^{15}$ The strength of evidence for each of the articles were judged based on the study design, assigning a level from 1 (high quality, low risk of bias) to 5 (low quality, high risk of bias). Any disagreement between two reviewers were resolved by discussion. 
medRxiv preprint doi: https://doi.org/10.1101/2021.01.19.21250059; this version posted January 20, 2021. The copyright holder for this preprint (which was not certified by peer review) is the author/funder, who has granted medRxiv a license to display the preprint in

All rights reserved. No reuse allowed without permission.

The overall response rates and $95 \%$ confidence intervals $(\mathrm{Cls})$, including clinical response, clinical remission, endoscopic response and mucosal healing, were estimated using random intercept logistic regression models. This was performed using the metaprop function in the meta package (version 4.12-0) in $\mathrm{R}$ (version 3.6.3). For the rate of discontinuation, the events including IBD-related surgery, switch of therapy and serious adverse events were combined. Statistical heterogeneity described the percentage of total variation across studies that are attributable to between-study heterogeneity. This was determined using the $\mathrm{Q}$ statistic of $\mathrm{I}^{2}$. $A n I^{2}$ value of more than $50 \%$ represented significant statistical heterogeneity.

\section{Results}

Study selection

The EMBASE literature search identified a total of 1260 publications. After the initial screening based on paper abstracts, 44 full text articles were reviewed. Twenty-one articles were considered eligible for meta-analysis following the application of inclusion and exclusion criteria. (Figure 1).

\section{Grading of Evidence}

Thirteen studies were graded as level 4 strength of evidence and eight studies were graded as level 3 (Table 1). This included a single randomized controlled trial for which the strength of evidence was graded as 3 on the basis of small absolute effect size.

\section{Study characteristics}

A total of 21 studies were included in this analysis; 13 retrospective studies, 7 cohort studies, and 1 randomized controlled trial. Thirteen of the 21 studies defined chronic pouchitis at baseline as the prolonged use of antibiotics for 4 weeks or more; while the remainder defined it as ongoing symptoms despite antibiotic use. Endoscopic confirmation of pouchitis at baseline was performed in 16 studies. Interventions included in the meta-analysis were ustekinumab ( 2 articles), vedolizumab (6 articles), infliximab (10 articles), adalimumab (4 articles), tacrolimus enema ( 1 article), thiopurine ( 1 article) and combination therapy of infliximab and thiopurine ( 1 article). All therapies were administered at recommended standard dosing regimens for ulcerative colitis.

A total of 491 patients from these studies were pooled for analysis, where the largest two cohorts were treated with either infliximab $(n=185)$, or vedolizumab $(n=153)$ (Table 1). Approximately $50 \%(n=247)$ of patients were female, with age ranging from 22 to 54 years. The reported age of pouch at commencement of intervention ranged from 1 to 10 years, based upon available data reported in 13 studies. The mean follow-up period ranged from 2 to 12 months.

Fifteen articles assessed clinical and endoscopic outcome, as well as discontinuation rate, 2 articles reported only clinical and endoscopic outcomes, another article reported only the endoscopic outcome, and 3 articles reported solely on the discontinuation rate (Figure 1).

\section{Clinical Response}


medRxiv preprint doi: https://doi.org/10.1101/2021.01.19.21250059; this version posted January 20, 2021. The copyright holder for this preprint (which was not certified by peer review) is the author/funder, who has granted medRxiv a license to display the preprint in perpetuity.

All rights reserved. No reuse allowed without permission.

Clinical response was assessed in 14 studies (Table 1 and Figure 2a), with the infliximab cohort making up the largest proportion of the sample, followed by vedolizumab, adalimumab, ustekinumab and lastly, tacrolimus. The overall pooled clinical response rate was $49 \%$ (95\% $\mathrm{Cl}, 36-62 \% ; 14$ studies, $175 / 351$ patients). There was statistically significant between-study heterogeneity; $I^{2}$ value of $79 \%(P>0.01)$. Clinical response was achieved in $41 \%$ of patients who received infliximab (95\% Cl 21-65\%); $42 \%$ of vedolizumab (95\% Cl 33-51\%), 55\% of adalimumab (95\% Cl 9-93\%), 59\% of ustekinumab (95\% Cl 48-69\%) and $90 \%$ of tacrolimus (95\% Cl 53-99\%). Between-study heterogeneity was evident only for infliximab treatment clinical response analyses $\left(I^{2}=77 \% ; P<0.01\right)$. The other interventional cohort studies, including ustekinumab, vedolizumab and adalimumab, showed low to moderate betweenstudy heterogeneity.

\section{Secondary Outcomes}

\section{Clinical Remission}

Eighteen studies reported on rates of clinical remission (Table 1 and Figure $2 b$ ). The majority of reported patients $(n=408)$ received infliximab $(n=149,37 \%)$ or vedolizumab $(n=147,36 \%)$; while adalimumab, ustekinumab and tacrolimus made up a small proportion of the total cohort. The pooled clinical remission rate for immunomodulator and biologic therapies was $34 \%(95 \% \mathrm{Cl} 21-50 \%)$ with a high degree of between-study heterogeneity $\left(I^{2}=86 \%, P<0.01\right)$. Clinical remission was observed in $51 \%$ of patient treated with infliximab ( $95 \% \mathrm{Cl} 36-66 \%$ ), $13 \%$ of patient treated with vedolizumab $(95 \% \mathrm{Cl} 2-56 \%), 31 \%$ treated with adalimumab $(95 \%$ $\mathrm{Cl} 17-51 \%), 7 \%$ treated with ustekinumab (95\% Cl 3-18\%) and $70 \%$ of patients treated with tacrolimus (95\% Cl 38-90\%). Low to moderate between-study heterogeneity was found in the infliximab and adalimumab cohorts, while between-study heterogeneity was found to be moderate to high in the vedolizumab cohort $\left(I^{2}=93 \% ; P<0.01\right)$.

\section{Endoscopic Response}

Twelve studies evaluated endoscopic response (Table 1 and Figure 2c). The overall endoscopic response rate for these studies was $53 \%$ (95\% Cl 33-71\%). There was substantial betweenstudy heterogeneity with $I^{2}$ value of $81 \%(P=0.03)$. Patients receiving vedolizumab accounted for more than half $(n=109,55 \%)$ of the pooled cohort analysed for endoscopic response rate with an individual endoscopic response rate of $67 \%$ (95\% $\mathrm{Cl} 49-81 \%)$. The remainder of the pooled cohort consisted of patients receiving ustekinumab, infliximab, adalimumab and tacrolimus in order of decreasing sample size. The endoscopic response rate for these groups was $52 \%$ (95\% Cl 35-68\%), 20\% (95\% Cl 8-43\%), 27\% (95\% Cl 7-64\%) and 100\% (95\% Cl 0$100 \%)$ respectively.

\section{Endoscopic Remission}

Fifteen studies reported endoscopic remission (Table 1 and Figure 2d). The combined results demonstrated a pooled endoscopic remission rate of $36 \%$ (95\% Cl 22-53\%) with significant heterogeneity; $I^{2}$ value of $72 \%(P<0.01)$. Vedolizumab therapy contributed to the majority of the sample population with endoscopic remission rate reported. Endoscopic remission was was seen in $57 \%$ of patient treated with infliximab (95\% Cl $44-70 \%), 20 \%$ treated with vedolizumab (95\% Cl 5-58\%), 41\% treated with adalimumab (95\% Cl 23-62\%), 3\% treated with ustekinumab (95\% $\mathrm{Cl} 0-18 \%)$ and $5 \%$ treated with tacrolimus (95\% $\mathrm{Cl} \mathrm{0-45 \% ).} \mathrm{There} \mathrm{was} \mathrm{low}$ to moderate between-study heterogeneity reported in most studies, with an $l^{2}$ of $0-16 \%$, except for those vedolizumab studies endoscopic remission analyses $\left(I^{2}=81 \% ; P<0.01\right)$. 
medRxiv preprint doi: https://doi.org/10.1101/2021.01.19.21250059; this version posted January 20, 2021. The copyright holder for this preprint (which was not certified by peer review) is the author/funder, who has granted medRxiv a license to display the preprint in

All rights reserved. No reuse allowed without permission.

\section{Discontinuation of therapy}

Eighteen studies documented the rate of discontinuation at the end of follow up period, ranging from 2 to 38 months (Table 2). The highest rate of discontinuation was reported in cohorts receiving adalimumab (up to 77\%), followed by infliximab (up to $74 \%$ ), and the combination therapy of infliximab and thiopurine (56\%). Ustekinumab and vedolizumab cohorts reported lower discontinuation rates of $13-20 \%$ and $0-36 \%$ respectively. One cohort study reported discontinuation rates of tacrolimus as $0 \%$ and thiopurine as $13 \%$. The main reason for discontinuation was lack of response.

The need for surgical interventions, including end ileostomy and anastomotic stricture dilatation, were observed. These procedures were more frequently seen in the cohort of patients treated with combination infliximab and thiopurine therapy (56\%). Other biologic monotherapies, namely adalimumab, infliximab and vedolizumab, were found to have similar surgical interventional rates, in the range of $15-40 \%, 0-30 \%$ and $0-46 \%$ respectively. Surgical intervention was observed in $20 \%$ of the single ustekinumab study.

Adverse events were reported by most of the studies (15/20 articles). Serious infections, including Clostridium difficile infection, Norovirus, sepsis, intra-abdominal abscess and Shingles, were reported in $2 \%$ of ustekinumab cohort, $3.6 \%$ of vedolizumab cohort and $12 \%$ of infliximab cohort. Serious adverse events, in particular anaphylaxis and delayed hypersensitivity reaction, were only observed with infliximab (up to 10\%) and adalimumab (15\%). Pancreatitis was documented in $13 \%$ of patients in the thiopurine cohort. Mild adverse events, for example, headache, injection site reaction, nausea and rash, were most common in the infliximab intervention group, with the highest reported rate of $39 \%$. Adalimumab was also found to have similar mild adverse events with a rate of up to $24 \%$. Thirty percent of tacrolimus enema cohort reported mild burning in the pouch upon application. Low rates of mild adverse events were noted in the vedolizumab cohort (up to 15\%) and none in the ustekinumab cohort.

\section{Discussion}

Although antibiotics such as ciprofloxacin and metronidazole are effective in induction of remission for acute pouchitis ${ }^{1}$, a proportion develop CADP or CARP. Second line therapies including steroids, bismuth, elemental diet and faecal microbiota transplant failed to achieve significant rates of clinical remission in a recent meta-analysis. ${ }^{1}$ Effective treatments for chronic pouchitis are required given its significant burden not only on physical health and quality of life, but also due to the significant associated economic burden. ${ }^{16}$ Immunomodulator and biologic therapies for chronic pouchitis have been evaluated in several studies recently and this study reviews this data. To date, and to the best of the authors knowledge, this is the most comprehensive meta-analysis of real-world data from peer-reviewed full-text manuscripts, focusing on immunomodulator and biologic therapies in chronic pouchitis.

Many medical therapies have been investigated for the treatment of chronic pouchitis in the last decade. A systemic review by Segal et al. in 2017 examined 21 studies that assessed the efficacy of steroids, bismuth, elemental diet, tacrolimus and faecal microbiota 
medRxiv preprint doi: https://doi.org/10.1101/2021.01.19.21250059; this version posted January 20, 2021. The copyright holder for this preprint (which was not certified by peer review) is the author/funder, who has granted medRxiv a license to display the preprint in perpetuity.

All rights reserved. No reuse allowed without permission.

transplantation. ${ }^{1}$ It concluded that none of these therapies achieved significant rates of response in chronic pouchitis. ${ }^{1}$ A Cochrane Review from 2019 examining 5 articles evaluating the efficacy of probiotics, bismuth enema, glutamine suppository, butyrate suppository and adalimumab for treatment of chronic pouchitis showed similar results. ${ }^{6}$

The pathogenesis of pouchitis remains uncertain. Acute pouchitis is believed to be driven by a bacterial etiology, explaining the responsiveness to antibiotic therapy. ${ }^{17}$ Many studies have suggested that the development of chronic pouchitis is multi-factorial, similar to inflammatory bowel disease itself. The proposed etiologies for development of chronic pouchitis include recurrence of ulcerative colitis, bacterial dysbiosis within the ileo-anal pouch, immune dysregulation, mucosal ischemia and oxygen-free radical injury, reduction in short-chain fatty acids and genetic predisposition. ${ }^{18}$ Histologically, ileal pouch mucosa shows colonic metaplasia with increased crypt cell proliferation and chronic inflammatory cell infiltrate within the lamina propria. ${ }^{18}$ Given that the histological features are analogous to ulcerative colitis, it is plausible that immunomodulators and biologic therapies used in induction and maintenance of ulcerative colitis would be beneficial in the setting of chronic pouchitis.

A single cohort study of 10 patients receiving tacrolimus enemas was included in this metaanalysis. The clinical response (90\%), clinical remission (70\%) and endoscopic response (100\%) rates were found to be the highest among all immunomodulator and biologic interventions. The results of this study must be interpreted with caution due to the small sample size. Endoscopic remission or mucosal healing was only found in $5 \%$ of patients, suggesting that topical tacrolimus may be useful in inducing short term clinical response, but not necessarily mucosal healing. Although none of the patients discontinued therapy at the end of follow up period, $30 \%$ reported mild burning sensation upon local application and no patient was able to tolerate the applied tacrolimus for 10 minutes. No serious adverse events were documented supporting the relative safety of local tacrolimus application.

Thiopurine use in chronic pouchitis was reported in a retrospective study of 8 patients, which focused on the safety profile of therapy. Efficacy was not able to be assessed as clinical and endoscopic responses were not reported. After 38 months of follow-up, one male patient (13\%) discontinued therapy due to acute pancreatitis. Thiopurine-induced pancreatitis is a well recognised complication occurring in approximately $3 \%$ of patients treated with thiopurines and is more common in females. ${ }^{19}$ The higher frequency noted in this study likely relates to the small sample size.

In our meta-analysis the largest cohort of patients was treated with infliximab and was associated with high clinical and endoscopic remission rates of $51 \%\left(95 \% \mathrm{Cl} 36-66 \% ; I^{2}=58 \%\right.$; 7 studies; $58 / 147$ patients) and $57 \%$ (95\% Cl 44-70\%; $I^{2}=16 \% ; 6$ studies; $47 / 84$ patients) respectively, similar to previous results. ${ }^{1}$ Clinical response was reported in a proportion of studies and was achieved in 41\% (95\% Cl 21-65\%; $I^{2}=77 \%$; 5 studies; $59 / 114$ patients) of patients, however there was significant heterogeneity between studies. The reported endoscopic response rate was low at $20 \%$ (95\% Cl 8-43\%; $I^{2}=0 \% ; 2$ studies; $4 / 20$ patients). The contrast in rates of clinical and endoscopic response versus remission may reflect differences in available data as there was significant variability in outcomes reported amongst studies. The discontinuation rate in the infliximab cohort was noted to be as high as $74 \%$ in 
medRxiv preprint doi: https://doi.org/10.1101/2021.01.19.21250059; this version posted January 20, 2021. The copyright holder for this preprint (which was not certified by peer review) is the author/funder, who has granted medRxiv a license to display the preprint in

All rights reserved. No reuse allowed without permission.

one of the retrospective studies. Reasons for discontinuation include non-response, loss of response and adverse events. Up to $30 \%$ of patients proceeded to formation of a permanent end-ileostomy at the end of follow up period. Almost $10 \%$ of patients suffered serious adverse events, including anaphylaxis, delayed hypersensitivity and drug-induced lupus. In addition, up to $12 \%$ of patients had severe infection, in particular, sepsis and Shingles. Overall infliximab was effective for clinical and endoscopic outcomes; however, the safety profile must be considered in patients receiving infliximab for CARP or CADP.

Similarly, adalimumab use in chronic pouchitis was associated with high rates of discontinuation and progression to surgical management, up to $77 \%$ and $40 \%$ respectively. A proportion of patients suffered adverse events, including delayed hypersensitivity (15\%), headache and injection site reaction (24\%). No serious infections were reported. This suggested a more tolerable safety profile for adalimumab, similar to previous published data. ${ }^{20}$ Overall clinical and endoscopic remission rate of adalimumab were noted to be $31 \%$ and $41 \%$ respectively, with low between-study heterogeneity. The lower rates of response with adalimumab may be due to differences in the patient populations reported, particularly the inclusion of patients who had previously failed infliximab in studies examining adalimumab. It is important to note that the one RCT included in this analysis was of adalimumab, and there was no significant difference in response between placebo and adalimumab arms, although this was a small study. In our analysis the adalimumab cohort had a reasonably high clinical response rate of $55 \%$, but the large confidence interval $195 \% \mathrm{Cl}$ 9-93\%) suggests that the true effect remains unclear. Taken together these results raise questions as to the efficacy of adalimumab for treatment of chronic pouchitis.

There were 6 full text articles assessing efficacy of vedolizumab in chronic pouchitis retrospectively, including patients who previously failed anti-tumor necrosis factor (anti-TNF) therapy. Clinical and endoscopic response rates were $42 \%$ and $67 \%$ respectively, without significant between-study heterogeneity. However clinical and endoscopic remission rates were poor at $13 \%$ and $20 \%$ respectively, with substantial between-study heterogeneity. This may reflect the slower onset of action of vedolizumab as well as a lack of correlation between endoscopic and clinical outcomes in pouchitis. The rate of discontinuation and surgical outcomes were both up to $36 \%$, which is lower than seen with infliximab or adalimumab. With respect to the safety profile of vedolizumab, there were 3 cases of serious infection (6\%), which included $C$. difficile infection, norovirus and intraabdominal sepsis. No serious adverse events were reported. Vedolizumab appears to achieve clinical and endoscopic response with a favourable safety profile. A similar safety profile to placebo was reported in post-marketing data with vedolizumab. ${ }^{21}$

Ustekinumab was recently approved for use in IBD, and there were only two published retrospective studies assessing the efficacy of ustekinumab on chronic pouchitis. A large proportion of patients (70\%) were anti-TNF-experienced prior ustekinumab treatment. All participants received ustekinumab throughout the follow up period of the study (median follow up period of 12-13 months). The clinical response and endoscopic response rates were high at $59 \%$ and $52 \%$ respectively, with negligible between-study heterogeneity. In comparison to the published data on the efficacy of ustekinumab in ulcerative colitis at the end of induction phase, the clinical response rate in chronic pouchitis was similar but a lower endoscopic improvement rate was observed. ${ }^{22-23}$ However, clinical remission and endoscopic 
medRxiv preprint doi: https://doi.org/10.1101/2021.01.19.21250059; this version posted January 20, 2021. The copyright holder for this preprint (which was not certified by peer review) is the author/funder, who has granted medRxiv a license to display the preprint in perpetuity.

All rights reserved. No reuse allowed without permission.

healing rates were quite low at $7 \%$ and $3 \%$ respectively. The rate of discontinuation was up to $20 \%$ due to loss of response and $8 \%$ progressed to a permanent end-ileostomy. There was a single case of $C$. difficile infection reported and no other serious adverse events. The percentage of serious infections was similar to the published data. These data suggest that ustekinumab is safely able to achieve clinical and endoscopic responses, but not necessarily remission during the follow-up period in the published studies.

This study provides an up to date comprehensive review and analysis of the available studies examining immunomodulator and biologic therapy for the treatment of chronic pouchitis. There are, however, several limitations to this study. Most studies included in this metaanalysis were single centred cohort studies with small sample sizes. Only one randomised placebo-controlled trial was included, however the small study population $(n=6)$ compromises the quality of those results. The lack of high-quality head-to-head trials and the heterogeneity of the patient populations studied, makes it challenging to compare the benefit of one drug to another; and conclusions about the comparative efficacy of each agent cannot be drawn from the available data. For these reasons, data should be interpreted with caution. Through our analysis, we also found that inconsistent definitions of chronic pouchitis are used in the literature. The considerable between-study heterogeneity suggested the different disease activity measures used to assess response and remission, which impact the extrapolation of these findings to clinical practice. To overcome these limitations, large-scale multi-centre randomised placebo-controlled trials with a consensus definition of chronic pouchitis and the standardized outcome measures are required.

\section{Conclusion}

Treatment of chronic antibiotic-refractory and antibiotic-dependent pouchitis remains challenging due to a lack of evidence guiding therapeutic decisions. This review and metaanalysis of real-world studies identified the effectiveness of vedolizumab and ustekinumab in achieving clinical and endoscopic response in chronic pouchitis, with a reassuring safety profile. Infliximab was found to be effective in inducing clinical and endoscopic remission, but there were significant rates of treatment failure and adverse events. Adalimumab demonstrated high rates of treatment discontinuation and progression to surgical outcomes despite reasonable clinical and endoscopic remission rates. There is limited published data regarding the use of immunomodulators for chronic pouchitis and no conclusion can be drawn. Further studies are required but current evidence favors vedolizumab, ustekinumab and infliximab for treatment of CADP or CARP.

\section{Reference}

1. Segal JP, Ding NS, Worley G, et al. Systemic review with meta-analysis: the management of chronic refractory pouchitis with an evidence-based treatment algorithm. Aliment Pharmacol Ther 2017;45:581-592.

2. Targownik LE, Singh $H$, Nugent $Z$, et al. The epidemiology of colectomy in ulcerative colitis: results from a population-based cohort. Am J Gastroenterol 2012;107:1228-1235.

3. Lepisto $A$, Luukkonen $P$, Jarvinen HJ. Cummulative failure rate of ileal pouch-anal anastomosis and quality of life after failure. Dis Colon Rectum 2002;45:1289-1294. 
medRxiv preprint doi: https://doi.org/10.1101/2021.01.19.21250059; this version posted January 20, 2021. The copyright holder for this preprint (which was not certified by peer review) is the author/funder, who has granted medRxiv a license to display the preprint in All rights reserved. No reuse allowed without permission.

4. Barnes EL, Herfarth HH, Sandler RS et al. Pouch-related symptoms and quality of life in patients with ileal-pouch-anal anastomosis. Inflamm Bowel Dis 2017;23(7):1218-1224.

5. Nyugen N, Zhang B, Holubar SD et al. Treatment and prevention of pouchitis after ileal pouch-anal anastomosis for chronic ulcerative colitis (Review). Cochrane Database of Systemic Reviews 2019;5.

6. Heuschen UA, Allemeyer EH, Hinz $U$, et al. Diagnosing pouchitis: comparative validation of two scoring systems in routine follow-up. Dis Colon Rectum 2002;45:776-786.

7. Di Febo G, Miglioli M, Lauri A, et al. Endoscopic assessment of acute inflammation of the reservoir after restorative ileoanal anastomosis. Gastrointestinal Endoscopy 1990;36(1):6-9.

8. Shepherd NA, Jass JR, Duval I et al. Restorative proctocolectomy with ileal reservoir: pathological and histochemical study of mucosal biopsy specimens. Journal of Clinical Pathology 1987;40(6):601-7.

9. Sandborn WJ. Pouchitis following ileal pouch-anal anastomosis: definition, pathogenesis, and treatment. Gastroenterology 1994;107(6):1856-60.

10. Sandborn WJ, Tremiane WJ, Batts KP, et al. Pouchitis following ileal pouch-anal anastomosis: a pouchitis disease activity index. Mayo Clinic Proceedings 1994;69(5):409415.

11. Magro F, Gionchetti P, Eliakim R, et al. Third European evidence-based consensus on diagnosis and management of ulcerative colitis. Part 1: Definitions, diagnosis and extraintestinal manifestations, pregnancy, cancer surveillance, surgery and ileo-anal Pouch Disorders. J Crohns Colitis 2017;11:649-670.

12. Mimura $T$, Rizzello $F$, Helwig $U$ et al. Four-week open-label trial of metronidazole and ciprofloxacin for the treatment of recurrent or refractory pouchitis. Aliment Pharmacol Ther 2002;16(5):909-917.

13. Dalal RL, Shen B, Schwartz DA. Management of pouchitis and other common complications of the pouch. Inflamm Bowel Dis 2018;24:989-996.

14. Bar F, Kuhbacher T, Dietrich NA, et al. Vedolizumab in the treatment of chronic, antibioticdependent or refractory pouchitis. Aliment Pharmacol Ther 2018;47:581-587.

15. OCEBM Levels of Evidence Working Group. The Oxford 2011 Levels of Evidence. http://www.cebm.net/wp-content/uploads/2014/06/CEBM-Levels-of-Evidence-2.1.pdf/

16. Lindsay JO, Bergman A, Patel AS, Alesso SM, Peyrin-Biroulet L. Systematic review: the financial burden of surgical complications in patients with ulcerative colitis. Aliment Pharmacol Ther 2015;41:1066-78.

17. Shen B. Acute and chronic pouchitis - pathogenesis, diagnosis and treatment. Nat Rev Gastroenterol 2012;9:323-333.

18. Schieffer KM, Williams ED, Yochum GS et al. Review article: the pathogenesis of pouchitis. Aliment Pharmacol Ther 2016;44:817-835.

19. Ledder O, Lemberg DA, Day AS. Thiopurine-induced pancreatitis in inflammatory bowel diseases. Expert Rev Gastroent 2015;9(4):399-403.

20. Sandborn WJ, Van Assche G, Reinisch W, et al. Adalimumab induces and maintains clinical remission in patients with moderate-to-severe ulcerative colitis. Gastroenterology 2012;142:257-265.e13.

21. Bye WA, Jairath V, Travis SPL. Systematic review: the safety of vedolizumab for the treatment of inflammatory bowel disease. Aliment Pharmacol Ther 2017;46:3-15.

22. Feagan BG, Sandborn WJ, Gasink C, et al. Ustekinumab as induction and maintenance therapy for Crohn's disease. N Engl J Med 2016;375:1946-1960. 
medRxiv preprint doi: https://doi.org/10.1101/2021.01.19.21250059; this version posted January 20, 2021. The copyright holder for this preprint (which was not certified by peer review) is the author/funder, who has granted medRxiv a license to display the preprint in All rights reserved. No reuse allowed without permission.

23. Sands BE, Sandborn WJ, Panaccione R, et al. Ustekinumab as induction and maintenance therapy for ulcerative colitis. N Engl J Med 2019;381:1201-1214.

24. Ollech JE, Rubin DT, Glick L, et al. Ustekinumab is effective for the treatment of chronic antibiotic-refractory pouchitis. Dig Dis Sci 2019;64:3596-3601.

25. Weaver KN, Gregory M, Syal G, et al. Ustekinumab is effective for the treatment of Crohn's disease of the pouch in a multicentre cohort. Inflamm Bowel Dis 2019;25(4):767-774.

26. Gregory M, Weaver KN, Hoversten $\mathrm{P}$, et al. Efficacy of vedolizumab for refractory pouchitis of ileo-anal pouch: Results from a multicenter US cohort. Inflamm Bowel Dis 2019;25(9):1569-1576.

27. Singh A, Khan F, Lopez R, et al. Vedolizumab for chronic antibiotic-refractory pouchitis. Gastroenterol Rep 2019;7(2):121-126.

28. Verstockt B, Claeys C, Hertogh GD, et al. Outcome of biological therapies in chronic antibiotic-refractory pouchitis: A retrospective single-centre experience. United Eur Gastroent 2019;7(9):1215-1225.

29. Bar F, Kuhbacher T, Dietrich NA, et al. Vedolizumab in the treatment of chronic, antibioticdependent or refractory pouchitis. Aliment Pharmacol Ther 2018;47:581-587.

30. Khan F, Gao XH, Singh A, et al. Vedolizumab in the treatment of Crohn's disease of the pouch. Gastroenterol Rep 2018;6(3):184-188.

31. Philpott J, Ashburn J, Shen B. Efficacy of vedolizumab in patients with antibiotic and antitumor necrosis alpha refractory pouchitis. Inflamm Bowel Dis 2017;23(1):e5-6.

32. Segal JP, Penez L, Elkady SM, et al. Long-term outcomes of initial infliximab for inflammatory pouch pathology: a multi-centre retrospective study. Scand J Gastroenterol 2018;53(9):1051-1058.

33. Kelly $O B$, Rosenberg $M$, Tyler $A D$, et al. Infliximab to treat refractory inflammation after pelvic pouch surgery for ulcerative colitis. J Crohns Colitis 2016;410-417.

34. Uchino $M$, Ikeuchi $H$, Bando $T$, et al. Clinical features of refractory pouchitis with penetrating lesions and the efficacy of infliximab treatment for patients with ulcerative colitis after restorative proctocolectomy. Digestion 2015;92:147-155.

35. Viazis N, Giakoumis M, Koukouratos $T$, et al. Long-term benefit of one-year infliximab administration for the treatment of chronic regractory pouchitis. J Crohns Colitis 2013;7:e457-460.

36. Barreiro-De Acosta M, Garcia-Bosch O, Souto R, et al. Efficacy of infliximab rescue therapy in patients with chronic refractory pouchitis: A multicenter study. Inflamm Bowel Dis 2012;18:812-817.

37. Haveran LA, Sehgal R, Poritz LS, et al. Infliximab and/or azathioprine in the treatment of Crohn's disease-like complications after IPAA. Dis Colon Rectum 2011;54:15-20

38. Ferrante $M$, D'Haens $G$, Dewit $O$, et al. Efficacy of infliximab in refractory pouchitis and Crohn's disease-related complications of the pouch: A Belgian case series. Inflamm Bowel Dis 2010;16(2)2:243-249.

39. Calabrese $C$, Gionchetti $P$, Rizzello F, et al. Short-term treatment with infliximab in chronic refractory pouchitis and ileitis. Aliment Pharmacol Ther 2008;27:759-764

40. Visicdo A, Kohn A, Papi C, et al. Management of refractory fistulizing pouchitis with infliximab. Eur Rev Med Pharmacol Sci 2004;8:239-246.

41. Kjaer MD, Qvist N, Nordgaard-Lassen I, et al. Adalimumab in the treatment of chronic pouchitis. A randomized double-blind, placebo-controlled trial. Scand J Gastroenterol 2019;54(2):188-193. 
medRxiv preprint doi: https://doi.org/10.1101/2021.01.19.21250059; this version posted January $20,2021$. The copyright holder for this preprint (which was not certified by peer review) is the author/funder, who has granted medRxiv a license to display the preprint in All rights reserved. No reuse allowed without permission.

42. Shen B, Remzi FH, Lavery IC, et al. Administration of adalimumab in the treatment of Crohn's disease of the ileal pouch. Aliment Pharmacol Ther 2009;29:519-526.

43. Barreiro-De Acosta M, Garcia-Bosch O, Gordillo J, et al. Efficacy of adalimumab rescue therapy in patients with chronic refractory pouchitis previously treated with infliximab: a case series. Eur J Gastroen Hepat 2012;24:756-758.

44. Uchino $M$, Ikeuchi $H$, Matsuoka $H$, et al. Topical tacrolimus therapy for antibioticrefractory pouchitis. Dis Colon Rectum 2013;56:1166-1173. 
medRxiv preprint doi: https://doi.org/10.1101/2021.01.19.21250059; this version posted January $20,2021$. The copyright holder for this preprint (which was not certified by peer review) is the author/funder, who has granted medRxiv a license to display the preprint in perpetuity.

All rights reserved. No reuse allowed without permission.

Table 1. Study characteristics and patient demographics from studies included in systemic literature review

\begin{tabular}{|c|c|c|c|c|c|c|c|c|c|c|c|c|}
\hline Study & $\begin{array}{c}\text { Types } \\
\text { of } \\
\text { study }\end{array}$ & $\begin{array}{c}\text { Interventi } \\
\text { on }\end{array}$ & $\begin{array}{l}\text { Total } \\
\text { cases }\end{array}$ & $\begin{array}{c}\text { Mean } \\
\text { age }\end{array}$ & Female & $\begin{array}{l}\text { Median } \\
\text { follow up } \\
\text { (month) }\end{array}$ & $\begin{array}{l}\text { Clinical } \\
\text { response }\end{array}$ & $\begin{array}{l}\text { Clinical } \\
\text { remission }\end{array}$ & $\begin{array}{c}\text { Endoscopic } \\
\text { response }\end{array}$ & $\begin{array}{l}\text { Endoscopic } \\
\text { remission }\end{array}$ & $\begin{array}{l}\text { Disco } \\
\text { ntinu } \\
\text { ation }\end{array}$ & $\begin{array}{c}\text { Assess } \\
\text { ment } \\
\text { of bias }\end{array}$ \\
\hline $\begin{array}{l}\text { Ollech } \\
\text { et al. } \\
2019\end{array}$ & $\begin{array}{l}\text { Retrosp } \\
\text { ective }\end{array}$ & $\begin{array}{c}\text { Ustekinu } \\
\text { mab }\end{array}$ & 24 & 35.6 & $\begin{array}{c}10 \\
(41.7 \%)\end{array}$ & 13 & $50.0 \%$ & - & $38.5 \%$ & $0.0 \%$ & $20 \%$ & 4 \\
\hline $\begin{array}{l}\text { Gregor } \\
\text { y et al. } \\
2019\end{array}$ & $\begin{array}{l}\text { Retrosp } \\
\text { ective }\end{array}$ & $\begin{array}{c}\text { Vedolizu } \\
\text { mab }\end{array}$ & 83 & - & $\begin{array}{c}45 \\
(54.2 \%)\end{array}$ & 15.5 & $41.0 \%$ & $16.9 \%$ & $55.4 \%$ & $14.9 \%$ & $36 \%$ & 4 \\
\hline $\begin{array}{l}\text { Verstoc } \\
\text { kt et al. } \\
2019\end{array}$ & $\begin{array}{l}\text { Retrosp } \\
\text { ective }\end{array}$ & $\begin{array}{c}\text { Vedolizu } \\
\text { mab }\end{array}$ & 15 & 49.7 & $\begin{array}{c}5 \\
(33.3 \%)\end{array}$ & 14.5 & - & $60.0 \%$ & - & - & $27 \%$ & 4 \\
\hline $\begin{array}{l}\text { Bar et } \\
\text { al. } 2018\end{array}$ & $\begin{array}{l}\text { Retrosp } \\
\text { ective }\end{array}$ & $\begin{array}{c}\text { Vedolizu } \\
\text { mab }\end{array}$ & 20 & 22.5 & $\begin{array}{c}8 \\
(40.0 \%)\end{array}$ & 3.5 & - & $45.0 \%$ & - & $64.3 \%$ & $0 \%$ & 4 \\
\hline $\begin{array}{l}\text { Khan et } \\
\text { al. } 2018\end{array}$ & $\begin{array}{l}\text { Retrosp } \\
\text { ective }\end{array}$ & $\begin{array}{c}\text { Vedolizu } \\
\text { mab }\end{array}$ & 12 & 41.0 & $\begin{array}{c}9 \\
(75.0 \%)\end{array}$ & 6 & $66.7 \%$ & $0.0 \%$ & $83.3 \%$ & $0.0 \%$ & - & 4 \\
\hline $\begin{array}{l}\text { Philpott } \\
\text { et al. } \\
2017\end{array}$ & $\begin{array}{l}\text { Retrosp } \\
\text { ective }\end{array}$ & $\begin{array}{c}\text { Vedolizu } \\
\text { mab }\end{array}$ & 4 & 53.8 & $\begin{array}{c}3 \\
(75.0 \%)\end{array}$ & 4 & - & - & $75.0 \%$ & $0.0 \%$ & - & 4 \\
\hline $\begin{array}{l}\text { Segal et } \\
\text { al. } 2018\end{array}$ & $\begin{array}{l}\text { Retrosp } \\
\text { ective }\end{array}$ & Infliximab & 34 & 25.0 & $\begin{array}{c}15 \\
(44.1 \%)\end{array}$ & 10 & - & - & - & - & $53 \%$ & 4 \\
\hline $\begin{array}{l}\text { Kelly et } \\
\text { al. } 2016\end{array}$ & $\begin{array}{l}\text { Retrosp } \\
\text { ective }\end{array}$ & Infliximab & 42 & 32.6 & $\begin{array}{c}28 \\
(66.6 \%)\end{array}$ & 24 & $73.8 \%$ & $47.6 \%$ & - & $45.2 \%$ & $38 \%$ & 4 \\
\hline $\begin{array}{l}\text { Uchino } \\
\text { et al. } \\
2015\end{array}$ & Pilot & Infliximab & 10 & 23.0 & $\begin{array}{c}7 \\
(70.0 \%)\end{array}$ & 2 & - & - & - & - & $30 \%$ & 3 \\
\hline $\begin{array}{l}\text { Viazis } \\
\text { et al. } \\
2013\end{array}$ & Pilot & Infliximab & 7 & 37.1 & $\begin{array}{c}4 \\
(57.1 \%)\end{array}$ & 12 & $14.3 \%$ & $71.4 \%$ & - & $71.4 \%$ & $14 \%$ & 3 \\
\hline $\begin{array}{l}\text { Barreir } \\
\text { o-De } \\
\text { Acosta } \\
\text { et al. } \\
2012\end{array}$ & $\begin{array}{l}\text { Retrosp } \\
\text { ective }\end{array}$ & Infliximab & 33 & 45.0 & $\begin{array}{c}15 \\
(45.5 \%)\end{array}$ & 12 & $33.3 \%$ & $33.3 \%$ & - & $40.0 \%$ & $39 \%$ & 4 \\
\hline $\begin{array}{l}\text { Havera } \\
\text { n et al. } \\
2011\end{array}$ & $\begin{array}{l}\text { Retrosp } \\
\text { ective }\end{array}$ & Infliximab & 4 & - & - & 38 & - & - & - & - & $25 \%$ & 4 \\
\hline
\end{tabular}


medRxiv preprint doi: https://doi.org/10.1101/2021.01.19.21250059; this version posted January 20, 2021. The copyright holder for this preprint (which was not certified by peer review) is the author/funder, who has granted medRxiv a license to display the preprint in perpetuity.

All rights reserved. No reuse allowed without permission.

\begin{tabular}{|c|c|c|c|c|c|c|c|c|c|c|c|c|}
\hline $\begin{array}{l}\text { Ferrant } \\
\text { e et al. } \\
2010\end{array}$ & Pilot & Infliximab & 25 & - & $\begin{array}{c}14 \\
(56.0 \%)\end{array}$ & 21 & $56.0 \%$ & $32.0 \%$ & $15.4 \%$ & $61.5 \%$ & $48 \%$ & 3 \\
\hline $\begin{array}{l}\text { Calabre } \\
\text { se et al. } \\
2008\end{array}$ & Pilot & Infliximab & 10 & 39.2 & $\begin{array}{c}4 \\
(40.0 \%)\end{array}$ & 6 & - & $80.0 \%$ & - & $80.0 \%$ & - & 3 \\
\hline $\begin{array}{l}\text { Kjaer at } \\
\text { al. } 2019\end{array}$ & $\begin{array}{c}\text { Rando } \\
\text { mised } \\
\text { control } \\
\text { trial }\end{array}$ & $\begin{array}{c}\text { Adalimum } \\
\text { ab }\end{array}$ & 6 & 40.1 & $\begin{array}{c}6 \\
(100.0 \\
\%)\end{array}$ & 3 & $100.0 \%$ & $16.7 \%$ & $66.7 \%$ & - & $17 \%$ & 2 \\
\hline $\begin{array}{l}\text { Shen et } \\
\text { al. } 2009\end{array}$ & Pilot & $\begin{array}{c}\text { Adalimum } \\
\text { ab }\end{array}$ & 17 & 36.0 & $\begin{array}{c}5 \\
(29.4 \%)\end{array}$ & 2 & $23.5 \%$ & $47.1 \%$ & $23.5 \%$ & $41.1 \%$ & $18 \%$ & 3 \\
\hline $\begin{array}{l}\text { Verstoc } \\
\text { kt et al. } \\
2019\end{array}$ & $\begin{array}{l}\text { Retrosp } \\
\text { ective }\end{array}$ & $\begin{array}{c}\text { Adalimum } \\
\text { ab }\end{array}$ & 13 & 39.3 & $\begin{array}{c}5 \\
(38.4 \%)\end{array}$ & 14.5 & - & $38.5 \%$ & - & - & $77 \%$ & 4 \\
\hline $\begin{array}{l}\text { Barreir } \\
\text { o-De } \\
\text { Acosta } \\
\text { et al. } \\
2012\end{array}$ & $\begin{array}{l}\text { Retrosp } \\
\text { ective }\end{array}$ & $\begin{array}{c}\text { Adalimum } \\
\text { ab }\end{array}$ & 10 & 43.2 & $\begin{array}{c}3 \\
(30.0 \%)\end{array}$ & 12 & $30.0 \%$ & $10.0 \%$ & $0.0 \%$ & $40.0 \%$ & $40 \%$ & 4 \\
\hline $\begin{array}{l}\text { Uchino } \\
\text { et al. } \\
2013\end{array}$ & Pilot & $\begin{array}{c}\text { Tacrolimu } \\
\mathrm{s}\end{array}$ & 10 & 39.0 & $\begin{array}{c}2 \\
(20.0 \%)\end{array}$ & 2 & $90.0 \%$ & $70.0 \%$ & $100.0 \%$ & $0.0 \%$ & $0 \%$ & 4 \\
\hline $\begin{array}{l}\text { Havera } \\
\text { n et al. } \\
2011\end{array}$ & $\begin{array}{l}\text { Retrosp } \\
\text { ective }\end{array}$ & $\begin{array}{c}\text { Thiopurin } \\
\text { e }\end{array}$ & 8 & - & - & 38 & - & - & - & - & $13 \%$ & 4 \\
\hline $\begin{array}{l}\text { Havera } \\
\text { n et al. } \\
2011\end{array}$ & $\begin{array}{l}\text { Retrosp } \\
\text { ective }\end{array}$ & $\begin{array}{c}\text { Infliximab } \\
+ \\
\text { Thiopurin } \\
\text { e }\end{array}$ & 9 & - & - & 38 & - & - & - & - & $56 \%$ & 4 \\
\hline
\end{tabular}


medRxiv preprint doi: https://doi.org/10.1101/2021.01.19.21250059; this version posted January 20, 2021. The copyright holder for this preprint (which was not certified by peer review) is the author/funder, who has granted medRxiv a license to display the preprint in perpetuity.

All rights reserved. No reuse allowed without permission.

Table 2. Reasons of discontinuation of therapy in real world cohort of chronic pouchitis.

\begin{tabular}{|c|c|c|c|c|c|c|c|c|c|c|c|}
\hline Study & $\begin{array}{l}\text { Interve } \\
\text { ntion }\end{array}$ & $\begin{array}{l}\text { Total } \\
\text { cases }\end{array}$ & $\begin{array}{l}\text { Median } \\
\text { follow up } \\
\text { (month) }\end{array}$ & $\begin{array}{c}\text { Discontin } \\
\text { uation } \\
(n, \%)\end{array}$ & $\begin{array}{l}\text { Loss of } \\
\text { response } \\
\text { (n) }\end{array}$ & $\begin{array}{l}\text { Switch of } \\
\text { biologic } \\
\text { therapy } \\
\text { (n) }\end{array}$ & $\begin{array}{l}\text { Surgical } \\
\text { interve } \\
\text { ntion } \\
\text { (n) }\end{array}$ & $\begin{array}{c}\text { Total } \\
\text { adverse } \\
\text { events } \\
(n, \%)\end{array}$ & $\begin{array}{c}\text { Serious } \\
\text { infection } \\
\text { (n) }\end{array}$ & $\begin{array}{c}\text { Serious } \\
\text { adverse } \\
\text { events (n) }\end{array}$ & $\begin{array}{c}\text { Mild } \\
\text { adverse } \\
\text { events } \\
\text { (n) }\end{array}$ \\
\hline $\begin{array}{l}\text { Ollech } \\
\text { et al. } \\
2019\end{array}$ & $\begin{array}{c}\text { Ustekin } \\
\text { umab }\end{array}$ & 24 & 13 & $\begin{array}{l}5 / 24 \\
20 \%\end{array}$ & - & 3 & $\begin{array}{c}2 \\
8 \%\end{array}$ & - & - & - & - \\
\hline $\begin{array}{l}\text { Weaver } \\
\text { et al. } \\
2019\end{array}$ & $\begin{array}{c}\text { Ustekin } \\
\text { umab }\end{array}$ & 56 & 12 & $\begin{array}{l}7 / 56 \\
13 \%\end{array}$ & 6 & - & - & $\begin{array}{c}1 / 56 \\
2 \%\end{array}$ & 1 & 0 & 0 \\
\hline $\begin{array}{l}\text { Gregor } \\
\text { y et al. } \\
2019\end{array}$ & $\begin{array}{c}\text { Vedoliz } \\
\text { umab }\end{array}$ & 83 & 15.5 & $\begin{array}{c}30 / 83 \\
36 \%\end{array}$ & - & 0 & $\begin{array}{c}30 \\
36 \%\end{array}$ & $\begin{array}{c}5 / 83 \\
6 \%\end{array}$ & 3 & 0 & 2 \\
\hline $\begin{array}{l}\text { Singh } \\
\text { et al. } \\
2019\end{array}$ & $\begin{array}{c}\text { Vedoliz } \\
\text { umab }\end{array}$ & 19 & 3 & $\begin{array}{l}4 / 19 \\
21 \%\end{array}$ & - & 0 & $\begin{array}{c}4 \\
21 \%\end{array}$ & $\begin{array}{l}2 / 19 \\
11 \%\end{array}$ & 0 & 0 & 2 \\
\hline $\begin{array}{l}\text { Verstoc } \\
\text { kt et al. } \\
2019\end{array}$ & $\begin{array}{c}\text { Vedoliz } \\
\text { umab }\end{array}$ & 15 & 14.5 & $\begin{array}{l}4 / 15 \\
27 \%\end{array}$ & 4 & 1 & 0 & $\begin{array}{c}0 / 15 \\
0 \%\end{array}$ & 0 & 0 & 0 \\
\hline $\begin{array}{l}\text { Bar et } \\
\text { al. } 2018\end{array}$ & $\begin{array}{c}\text { Vedoliz } \\
\text { umab }\end{array}$ & 20 & 3.5 & $\begin{array}{c}0 / 20 \\
0 \%\end{array}$ & 0 & 0 & 0 & $\begin{array}{l}3 / 20 \\
15 \%\end{array}$ & 0 & 0 & 3 \\
\hline $\begin{array}{l}\text { Verstoc } \\
\text { kt et al. } \\
2019\end{array}$ & $\begin{array}{c}\text { Inflixim } \\
\text { ab }\end{array}$ & 23 & 14.5 & $\begin{array}{c}17 / 23 \\
74 \%\end{array}$ & 8 & 13 & $\begin{array}{c}4 \\
17 \%\end{array}$ & $\begin{array}{l}9 / 23 \\
39 \%\end{array}$ & 0 & 1 & 8 \\
\hline $\begin{array}{l}\text { Segal et } \\
\text { al. } 2018\end{array}$ & $\begin{array}{c}\text { Inflixim } \\
\text { ab }\end{array}$ & 34 & 10 & $\begin{array}{c}18 / 34 \\
53 \%\end{array}$ & 18 & 8 & $\begin{array}{c}10 \\
29 \%\end{array}$ & $\begin{array}{l}4 / 34 \\
12 \%\end{array}$ & 4 & 0 & 0 \\
\hline $\begin{array}{l}\text { Kelly et } \\
\text { al. } 2016\end{array}$ & $\begin{array}{c}\text { Inflixim } \\
\text { ab }\end{array}$ & 42 & 24 & $\begin{array}{c}16 / 42 \\
38 \%\end{array}$ & 5 & 7 & $\begin{array}{c}9 \\
21 \%\end{array}$ & $\begin{array}{l}5 / 42 \\
12 \%\end{array}$ & 0 & 4 & 1 \\
\hline $\begin{array}{l}\text { Uchino } \\
\text { et al. } \\
2015\end{array}$ & $\begin{array}{c}\text { Inflixim } \\
\text { ab }\end{array}$ & 10 & 2 & $\begin{array}{l}3 / 10 \\
30 \%\end{array}$ & 3 & 0 & $\begin{array}{c}3 \\
30 \%\end{array}$ & - & - & - & - \\
\hline $\begin{array}{l}\text { Viazis } \\
\text { et al. } \\
2013\end{array}$ & $\begin{array}{c}\text { Inflixim } \\
\text { ab }\end{array}$ & 7 & 12 & $\begin{array}{l}1 / 7 \\
14 \%\end{array}$ & 1 & 0 & $\begin{array}{c}1 \\
14 \%\end{array}$ & $\begin{array}{c}1 / 7 \\
14 \%\end{array}$ & 0 & 0 & 1 \\
\hline $\begin{array}{l}\text { Barreir } \\
\text { o-De } \\
\text { Acosta } \\
\text { et al. } \\
2012\end{array}$ & $\begin{array}{c}\text { Inflixim } \\
\text { ab }\end{array}$ & 33 & 12 & $\begin{array}{c}13 / 33 \\
39 \%\end{array}$ & 13 & 0 & $\begin{array}{c}4 \\
12 \%\end{array}$ & $\begin{array}{l}5 / 33 \\
21 \%\end{array}$ & 0 & 1 & 4 \\
\hline $\begin{array}{l}\text { Havera } \\
\text { n et al. } \\
2011\end{array}$ & $\begin{array}{c}\text { Inflixim } \\
\text { ab }\end{array}$ & 4 & 38 & $\begin{array}{l}1 / 4 \\
25 \%\end{array}$ & 1 & 0 & $\begin{array}{c}1 \\
25 \%\end{array}$ & $\begin{array}{l}0 / 4 \\
0 \%\end{array}$ & 0 & 0 & 0 \\
\hline $\begin{array}{l}\text { Ferrant } \\
\text { e et al. } \\
2010\end{array}$ & $\begin{array}{c}\text { Inflixim } \\
\text { ab }\end{array}$ & 25 & 21 & $\begin{array}{c}12 / 25 \\
48 \%\end{array}$ & 9 & 0 & $\begin{array}{c}6 \\
24 \%\end{array}$ & $\begin{array}{c}2 / 25 \\
8 \%\end{array}$ & 0 & 2 & 0 \\
\hline
\end{tabular}


medRxiv preprint doi: https://doi.org/10.1101/2021.01.19.21250059; this version posted January 20, 2021. The copyright holder for this preprint (which was not certified by peer review) is the author/funder, who has granted medRxiv a license to display the preprint in

All rights reserved. No reuse allowed without permission.

\begin{tabular}{|c|c|c|c|c|c|c|c|c|c|c|c|}
\hline $\begin{array}{l}\text { Viscido } \\
\text { et al. } \\
2003\end{array}$ & $\begin{array}{c}\text { Inflixim } \\
\text { ab }\end{array}$ & 7 & 35 & $\begin{array}{l}0 / 7 \\
0 \%\end{array}$ & 0 & 0 & 0 & $\begin{array}{c}1 / 7 \\
14 \%\end{array}$ & 1 & 0 & 0 \\
\hline $\begin{array}{l}\text { Kjaer at } \\
\text { al. } 2019\end{array}$ & $\begin{array}{l}\text { Adalim } \\
\text { umab }\end{array}$ & 6 & 3 & $\begin{array}{l}1 / 6 \\
17 \%\end{array}$ & - & - & - & $\begin{array}{l}0 / 6 \\
0 \%\end{array}$ & 0 & 0 & 0 \\
\hline $\begin{array}{l}\text { Shen et } \\
\text { al. } 2009\end{array}$ & $\begin{array}{l}\text { Adalim } \\
\text { umab }\end{array}$ & 17 & 2 & $\begin{array}{l}3 / 17 \\
18 \%\end{array}$ & - & 0 & $\begin{array}{c}3 \\
18 \%\end{array}$ & $\begin{array}{l}4 / 17 \\
24 \%\end{array}$ & 0 & 0 & 4 \\
\hline $\begin{array}{l}\text { Verstoc } \\
\text { kt et al. } \\
2019\end{array}$ & $\begin{array}{l}\text { Adalim } \\
\text { umab }\end{array}$ & 13 & 14.5 & $\begin{array}{c}10 / 13 \\
77 \%\end{array}$ & 6 & 4 & $\begin{array}{c}2 \\
15 \%\end{array}$ & $\begin{array}{l}2 / 13 \\
15 \%\end{array}$ & 0 & 2 & 0 \\
\hline $\begin{array}{l}\text { Barreir } \\
\text { o-De } \\
\text { Acosta } \\
\text { et al. } \\
2012\end{array}$ & $\begin{array}{l}\text { Adalim } \\
\text { umab }\end{array}$ & 10 & 12 & $\begin{array}{l}4 / 10 \\
40 \%\end{array}$ & - & 0 & $\begin{array}{c}4 \\
40 \%\end{array}$ & - & - & - & - \\
\hline $\begin{array}{l}\text { Uchino } \\
\text { et al. } \\
2013\end{array}$ & $\begin{array}{c}\text { Tacroli } \\
\text { mus }\end{array}$ & 10 & 2 & $\begin{array}{c}0 / 10 \\
0 \%\end{array}$ & 0 & 0 & - & $\begin{array}{l}3 / 10 \\
30 \%\end{array}$ & 0 & 0 & 3 \\
\hline $\begin{array}{l}\text { Havera } \\
\text { n et al. } \\
2011\end{array}$ & $\begin{array}{c}\text { Thiopur } \\
\text { ine }\end{array}$ & 8 & 38 & $\begin{array}{l}1 / 8 \\
13 \%\end{array}$ & 0 & 1 & 0 & $\begin{array}{l}1 / 8 \\
13 \%\end{array}$ & 0 & 1 & 0 \\
\hline $\begin{array}{l}\text { Havera } \\
\text { n et al. } \\
2011\end{array}$ & $\begin{array}{c}\text { Inflixim } \\
\text { ab }+ \\
\text { Thiopur } \\
\text { ine }\end{array}$ & 9 & 38 & $\begin{array}{l}5 / 9 \\
56 \%\end{array}$ & - & 0 & $\begin{array}{c}5 \\
56 \%\end{array}$ & $\begin{array}{l}0 / 9 \\
0 \%\end{array}$ & 0 & 0 & 0 \\
\hline
\end{tabular}


medRxiv preprint doi: https://doi.org/10.1101/2021.01.19.21250059; this version posted January $20,2021$. The copyright holder for this preprint (which was not certified by peer review) is the author/funder, who has granted medRxiv a license to display the preprint in perpetuity.

All rights reserved. No reuse allowed without permission.

Figure 1. Inclusion of the studies for meta analyses of immunomodulator and biologic therapies in chronic pouchitis.

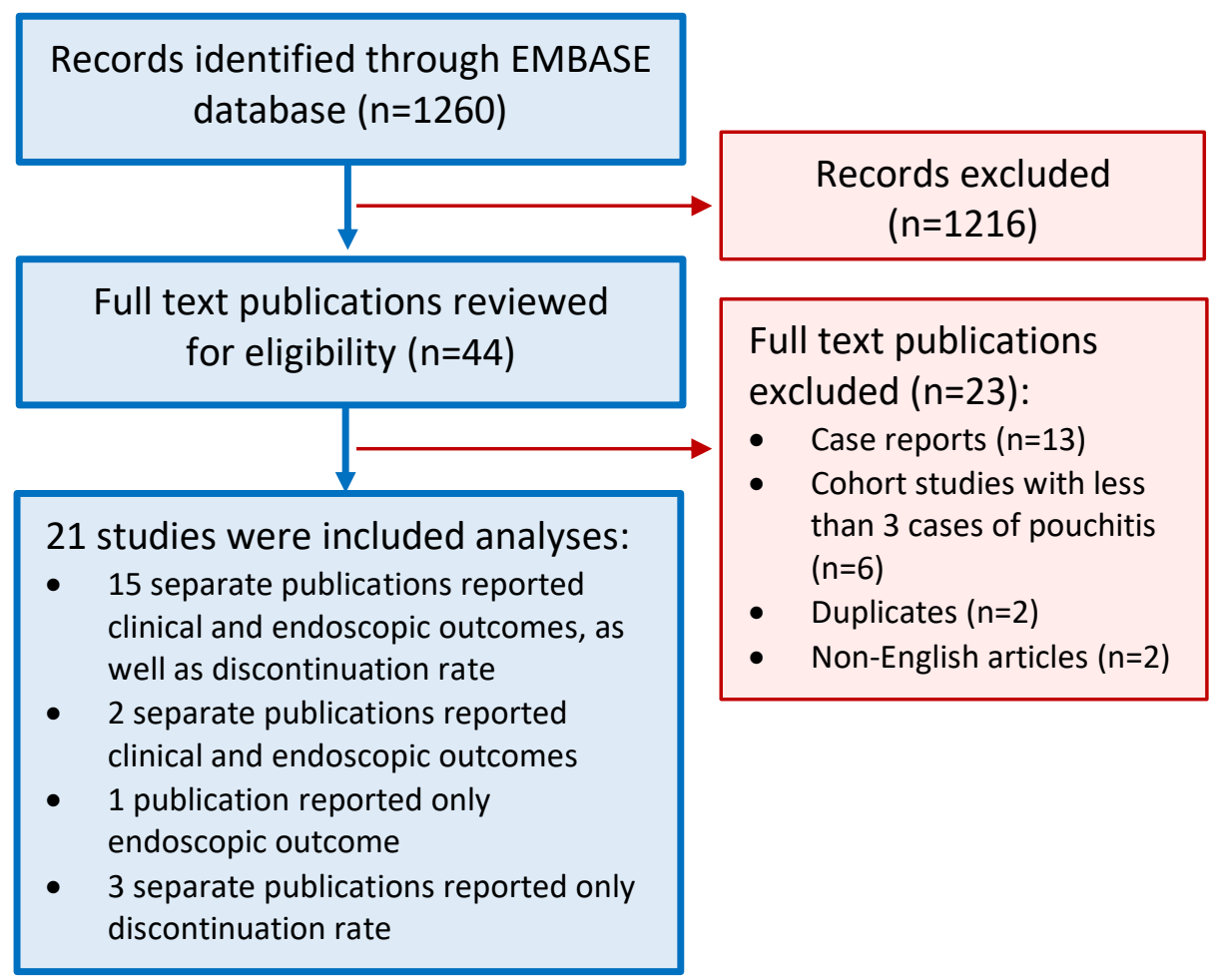


medRxiv preprint doi: https://doi.org/10.1101/2021.01.19.21250059; this version posted January 20, 2021. The copyright holder for this preprint (which was not certified by peer review) is the author/funder, who has granted medRxiv a license to display the preprint in perpetuity.

All rights reserved. No reuse allowed without permission.

Figure 2. Primary and secondary outcomes comparing the efficacy of each interventions

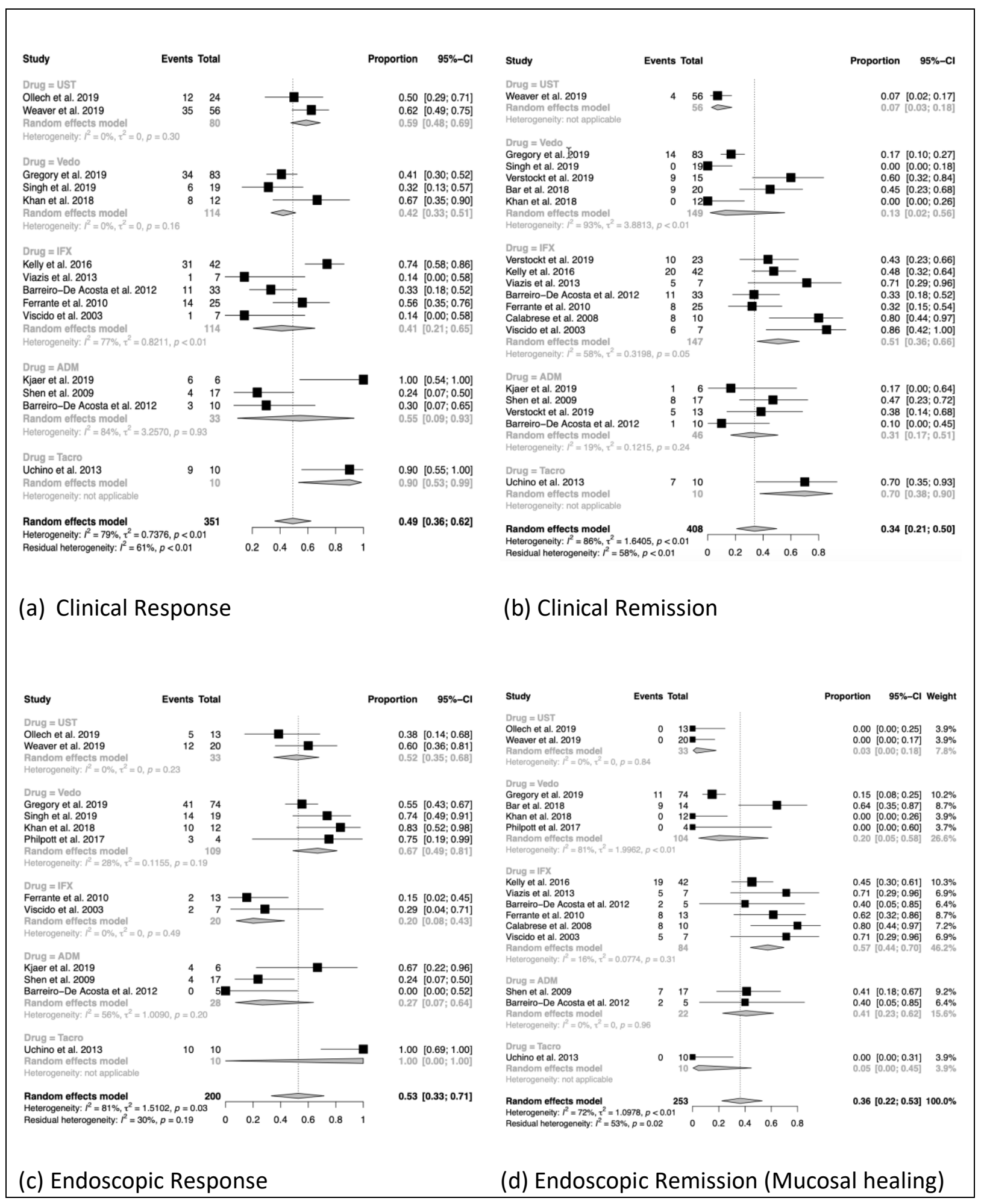

